\title{
Impact of external interferences on vibroacoustic signals coming from combustion engine during cold test
}

\begin{abstract}
In the paper is presented impact of external interferences on vibroacoustic signals coming from a spark ignition engine's vibrations in cold test performed on engine assembly line. As the basis to the analysis were used signals of piezoelectric sensor mounted on cylinder block of the engine driven by electric motor. In course of the testing it has been used the order tracking analysis of the vibrations during the cold test, while experimental results were used to statistic analysis of significance of influence with use of the MiniTab computer program. The main objective of the investigations was to verify actually obtained vibroacoustic signals and to minimize interferences coming from the measuring system. It should contribute to reduction of tolerance limits and improved detection of faulty engines with use of vibroacoustic methods. The investigations have shown significant impact of contact surface of the cylinder block with the sensor and impact of deformations of compression spring on results of recorded vibroacoustic signal. Such impact should be taken into considerations in numerical analysis of the signal. It has been proposed to perform activities to reduce influence of the interferences on recorded signals. Results of the investigations have been already utilized in production cold tests of spark ignition engines.
\end{abstract}

Key words: vibroacoustics, cold test, order tracking analysis

\section{Wpływ zakłóceń zewnętrznych na sygnały wibroakustyczne silnika spalinowego podczas testu zimnego}

\begin{abstract}
W artykule przedstawiono wpływ zakłóceń zewnętrznych na sygnały wibroakustyczne drgań silnika o zapłonie iskrowym podczas testu zimnego na linii produkcyjnej. Podstawa analiz byly sygnaty czujnika piezokwarcowego pochodzace z korpusu silnika spalinowego napędzanego silnikiem elektrycznym. W badaniach wykorzystano analizę rzędową drgań podczas testu zimnego, a wyniki doświadczalne poddano analizie statystycznej istotności oddziaływania z wykorzystaniem programu MiniTab. Podstawowym celem badań była weryfikacja aktualnie uzyskiwanych sygnałów wibroakustycznych i minimalizacja zaktóceń pochodzacych od układu pomiarowego. Powinno to prowadzić do zmniejszenia limitów tolerancji i poprawy wykrywalności silników wadliwych metodami wibroakustycznymi. Badania wykazały istotny wplyw stanu powierzchni styku czujnika z kadlubem i odkształcenia sprężyny dociskowej na wyniki rejestrowanego sygnatu wibroakustycznego. Wptyw ten należy uwzględniać w numerycznych analizach sygnału. Zaproponowano zabiegi zmniejszające oddziaływanie zakłóceń na rejestrowany sygnat. Wyniki badań moga być już obecnie wykorzystane w produkcyjnych testach zimnych silników o zaptonie iskrowym.
\end{abstract}

Słowa kluczowe: wibroakustyka, test zimny, analiza rzędowa

\section{Introduction}

The vibroacoustic signals are used increasingly for diagnosis of mechanical devices, both in manufacturing and in operation, aimed at detection of a defects having effect on correct operation of such devices. Vibroacoustic signal received from measurement of some physical quantities (the most often velocity and acceleration), characterizes vibrations of the tested object. Based on level of the vibrations it is possible to qualify the devices as good ones or faulty ones

In recent years the vibroacoustic signals have been used in manufacturing process of combustion engines, during final stages of assembly cycle in assembly line, during so called cold test. Complete combustion engine is driven by electric motor, while the vibroacoustic signals are recorded at predermined rotational speeds; and the signals are subsequently processed by computer program and compared to reference values. It enables to qualify the engines as good ones and faulty ones, and very often to identify a source of increased vibrations. All manufactured engines are subjected to such test, while the cold test stations are fully automated [7].

\section{Wstęp}

Sygnały wibroakustyczne w coraz szerszym zakresie są wykorzystywane do diagnostyki urządzeń mechanicznych zarówno w procesie produkcji, jak i eksploatacji do wykrywania defektów wpływających na poprawną ich pracę. Sygnał wibroakustyczny otrzymany przez pomiar pewnych wielkości fizycznych (najczęściej prędkości i przyspieszenia) charakteryzuje drgania obiektu badanego. Na podstawie poziomu drgań można kwalifikować urządzenia jako dobre i wadliwe.

$\mathrm{W}$ ostatnich latach sygnały wibroakustyczne wykorzystywane są w procesie produkcji silników spalinowych, na końcowych etapach linii montażowej, podczas tzw. testu zimnego. Kompletny silnik spalinowy jest napędzany silnikiem elektrycznym i przy określonych prędkościach obrotowych rejestrowane są sygnały wibroakustyczne, które następnie są obrabiane przez programy komputerowe i porównywane $z$ wartościami referencyjnymi. Pozwala to kwalifikować silniki na dobre i wadliwe oraz często wskazywać źródło zwiększonych drgań. Badaniom takim 
Faulty engines are transferred to so called hot test, during this test a scope of repair can be determined or final qualification of the engine is performed. Regardless of the cold test results, to the hot test is directed some percentage of the engines, even these qualified as $\mathrm{OK}$ in the cold test. It results from manufacturing standards of engine manufacturers, specific for each engine manufacturer.

During the cold tests of combustion engines the most often are used two vibroacoustic sensors attached to cylinder head and to cylinder block. Piezoelectric acceleration sensors are used the most often. Output signal from the sensor is proportional to acceleration of inertial mass of the sensor attached on the tested object (1).

$$
\text { vibrations }(\mathrm{dB})=20 \cdot \log _{10} \frac{\mathrm{a}}{\mathrm{a}_{\text {ref }}}
$$

where: vibrations $(\mathrm{dB})$ - number of decibels, a - measured acceleration, $a_{\text {ref }}$ - reference level of accelerations, the most often the assumption is that $\mathrm{a}_{\text {ref }}=10^{-5} \mathrm{~m} / \mathrm{s}^{2}$.

In the Fig. 1 is presented uniaxial sensor of accelerations of the ICP type, model 352C68, produced the PCB Piezotronice, used in course of diagnostic tests of combustion engines in cold test cabins, detailed description of this sensor can be found in the publication [7].

To analysis of recorded vibroacoustic signals of the engine the order tracking analysis was implemented [7-9], which effectively makes use of average values of amplitude of the vibrations in groups of orders with division of complete range of the orders into so called classes [8]. This method is often used to analysis of vibrations coming from single sources, and to analysis of complex vibrations.

During the cold test, control of complete engine subassemblies comprises verification of all manufactured engines. The control is performed automatically and in case of positive result, the engine is transferred to successive operations of the manufacturing process. Control of amplitude of engine vibrations is performed to eliminate assembly defects or faulty components of the engine. In the present paper is analyzed an influence of external interferences on the vibroacoustic signal of tested combustion engines.

\section{Attachment of the sensor on the engine}

Vibroacoustic control of combustion engine is performed using piezoelectric sensor, through direct contact of the sensing unit, perpendicularly to surface of cylinder block (Fig. 2). Due to serial production of combustion engines, measuring unit can't be permanently attached to the engine.

Within scope of the cold test is performed monitoring of vibrations during complete cycle of the test, and is performed a single control at rotational speed of $1500 \mathrm{rpm}$. In result of performed earlier stand tests it has been proposed to increase initial rotational speed from $1000 \mathrm{rpm}$ to $1500 \mathrm{rpm}$, what according to the authors has increased effectiveness of detection of some engine defects [9]. poddawane są wszystkie produkowane silniki, a stanowiska do testu zimnego są całkowicie zautomatyzowane [7]. Silniki wadliwe są przekazywane do tzw. testu ciepłego, podczas którego ustala się zakres napraw, albo dokonuje się ostatecznej kwalifikacji silnika. Niezależnie od wyników testu zimnego, do testu gorącego przeznaczana jest pewna część silników nawet tych, które w teście zimnym są zakwalifikowane jako dobre. Wynika to z norm fabrycznych producentów, indywidualnych dla każdej z firm.

Podczas testu zimnego silników spalinowych najczęściej stosowane są dwa czujniki wibroakustyczne mocowane do głowicy i kadłuba. Stosowane są najczęściej piezoelektryczne czujniki przyspieszeń. Sygnał wyjściowy czujnika jest proporcjonalny do przyspieszenia, jakiemu poddana jest masa bezwładna czujnika zamocowanego na badanym obiekcie (1), gdzie: drgania (dB) - liczba decybeli, a - mierzone przyspieszenie, $a_{\text {ref }}$ - poziom odniesienia przyspieszeń, najczęściej przyjmuje się $\mathrm{a}_{\text {ref }}=10^{-5} \mathrm{~m} / \mathrm{s}^{2}$.

$\mathrm{Na}$ rysunku 1 przedstawiono jednoosiowy czujnik przyspieszeń drgań firmy PCB Piezotronice typu ICP model 352C68, stosowany w czasie badań diagnostycznych silników spalinowych podczas testów zimnych, a jego szczegółowy opis jest zawarty w pracy [7].

Do analizy rejestrowanego sygnału wibroakustycznego silnika spalinowego zastosowano analizę rzędową [7-9], która wykorzystuje skutecznie średnie wartości amplitudy drgań w grupach rzędów z po-

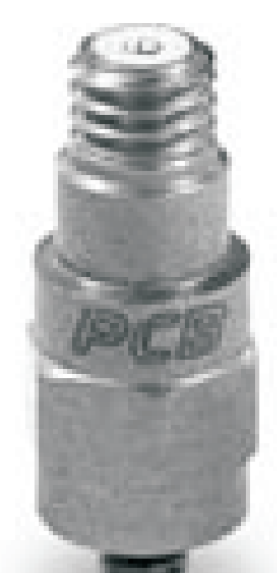
działem całego zakresu rzędów na tzw. klasy [8]. Metoda ta jest często stosowana do analizy drgań pochodzących ze źródeł pojedynczych i przy drganiach złożonych.
Fig. 1. Acceleration sensor of the ICP type, 352C68 model, made by the PCB Piezotronice [11]
Rys. 1. Czujnik przyspieszeń drgań PCB Piezotronice typu ICP model $352 C 68$ [11]

Podczas testu zimnego kontrola kompletnego silnika obejmuje weryfikację wszystkich produkowanych silników. Próba odbywa się automatycznie i przy uzyskaniu wyniku pozytywnego silnik przechodzi do dalszych etapów produkcyjnych. Kontroli podlega sprawdzanie amplitudy drgań silnika, w celu eliminacji wad montażowych lub wad części silnika. W tym artykule przedstawiono analizę wpływu zakłóceń zewnętrznych na sygnał wibroakustyczny badanego silnika spalinowego.

\section{Mocowanie czujnika na silniku}

Kontrola wibroakustyczna silnika spalinowego wykonywana jest czujnikiem piezoelektrycznym przez bezpośredni styk zespołu czujnika prostopadle do powierzchni korpusu (rys. 2). Ze względu na produkcję seryjną silników spalinowych zespół pomiarowy nie jest mocowany trwale do silnika. 

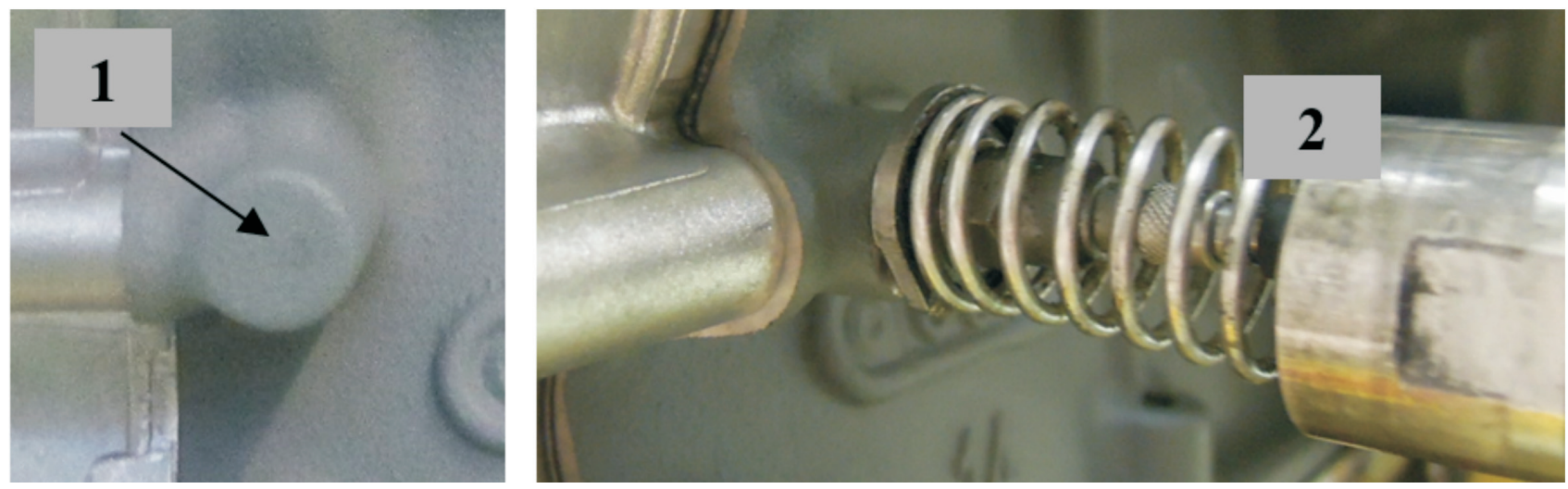

Fig. 2. Attachment of the piezoelectric sensor (measurement of vibrations of the cylinder block): 1 - position of contact of the cylinder block with the sensor, 2 - sensing unit during operation

Rys. 2. Mocowanie czujnika piezoelektrycznego (pomiar drgań korpusu): 1 - miejsce styku czujnika z kadtubem, 2 - zespół czujnika podczas pracy

\section{Impact of external interferences on the vibroacoustic signal}

The main recommendations of the sensor and diagnostic system manufacturers, concerning accelorometric test of a combustion engine, comprise:

- suitable fixing position,

- suitable method of attachment on a tested object,

- elimination of external interferences during operation of the accelerometer,

- ambient conditions (humidity, temperature, corrosive substances, etc.).

General cause and effect system and residual processes arisen during cold test of the combustion engine are shown in the Fig. 3.

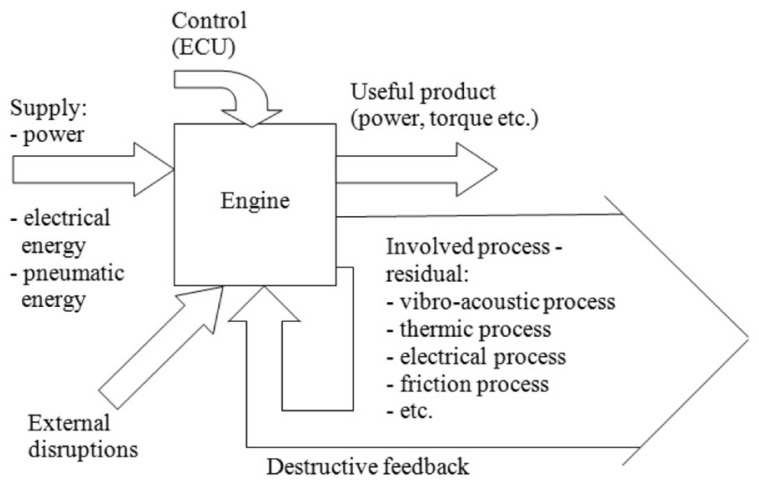

Fig. 3. Combustion engine as the cause system and generator of residual processes [3]

Rys. 3. Silnik spalinowy jako system działaniowy i generator procesów resztkowych [3]

The sensor is in contact with the cylinder block, being a tested object. Recommended measurement of the signal from radial direction occurs for the crankshaft, counterbalance shaft with bearings, and toothed wheels of the gear with ratio $1: 1$.

To external interferences belong: - deformations of the mount (object of the test),
W ramach testu zimnego przeprowadzany jest monitoring wibracji podczas całej próby oraz punktowa kontrola przy prędkości obrotowej $1500 \mathrm{obr} / \mathrm{min}$. W wyniku przeprowadzonych badań stanowiskowych zaproponowano zwiększenie pierwotnej prędkości obrotowej z $1000 \mathrm{obr} / \mathrm{min}$ do 1500 obr/min, co, zdaniem autorów, zwiększyło skuteczność wykrywalności niektórych wad silnika [9].

\section{Wpływ zakłóceń zewnętrznych na sygnal wibroakustyczny}

Podstawowe zalecenia producenta czujnika i systemu diagnostycznego dotyczące testu akcelerometrem silnika spalinowego obejmują:

- odpowiednią pozycję montażową,

- właściwy sposób mocowania z obiektem badań,

- eliminacje zakłóceń zewnętrznych dla pracy akcelerometru,

- warunki środowiskowe (wilgotność, temperatura, substancje korozyjne itp.).

Ogólny system działaniowo-skutkowy oraz procesy resztkowe powstałe podczas testu zimnego silnika spalinowego przedstawiono na rys. 3 .

Dla badanego obiektu czujnik styka się z korpusem silnika. Zalecany pomiar sygnału z kierunku promieniowego odbywa się dla wału korbowego, wałka wyrównoważającego z łożyskami oraz dla kół zębatych przekładni 1:1.

Do zakłóceń zewnętrznych należą:

- odkształcenia podstawy (obiektu badań),

- chropowatość podstawy,

- naprężenia zespołu pomiarowego,

- szumy w przewodach elektrycznych (tryboelektryczne, akustyczne),

- wibracje poprzeczne,

- promieniowanie radioaktywne oraz pola magnetyczne, - hałas.

Przy zachowaniu prawidłowych warunków prowadzenia testu można założyć, że pozycja i sposób mocowania czujnika dla pomiaru drgań pochodzących z korpusu są właściwe. Umożliwia to analizę wpływu następujących zakłóceń zewnętrznych: odkształcenia zespołu pomiarowego, szumów w 
- surface roughness of the mount,

- stresses of the measuring system,

- interference in electric wiring (triboelectrical, acoustic),

- lateral vibrations,

- radioactive radiation and magnetic field,

- noise.

While maintaining proper performance conditions for the test it is possible to assume that position and attachment method of the sensor to measurement of the vibrations coming from the cylinder block is appropriate. It enables analysis of effects of the following external interferences: deformations of the measuring system, interferences in electric wiring (triboelectrical) and roughness of the cylinder block on contact surface with the piezoelectric sensor. It is important to pay attention that ambient conditions (humidity, temperature, etc.) are normal.

\subsection{Impact of deformations of the} sensing unit on the vibroacoustic signal

Improper and non-uniform stresses in the measuring system (springs together

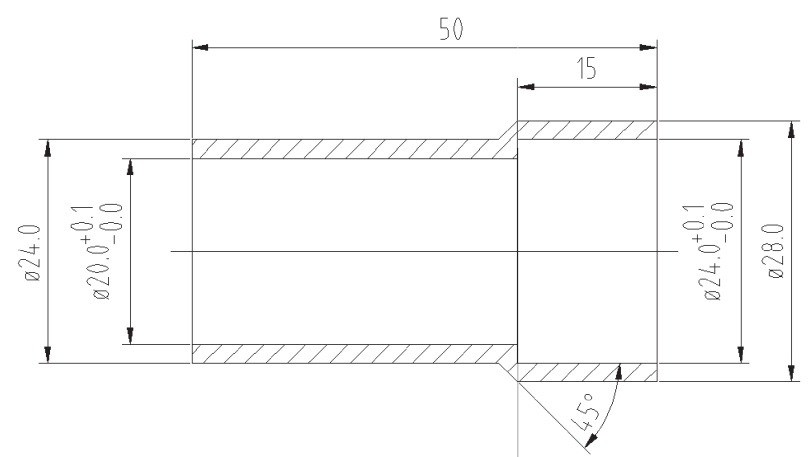

Fig. 5. The sleeve stabilizing spring of the sensor Rys. 5. Tulejka stabilizująca sprężynę czujnika

with accelerometer, Fig. 4) could create a source of significant interferences in measured vibrations. This effect can be minimized by use of a special sleeve stabilizing working path of the spring (Fig. 5 and 6).

Use of the stabilizing sleeve resulted in considerable reduction of amplitude of the vibrations in range of higher orders, higher than 65 (Fig. 7). Whereas in case of lower orders Ord $<25$, amplitudes of vibrations indicated by the system with the sleeve are higher, what should be read as an additional interference introduced by the sleeve.

\subsection{Impact of triboelectric interference arisen in case of free hanging wiring cable of the measuring system}

In case of vibrations of the electric cable of the sensor it is possible to generate przewodach (tryboelektryczne) oraz chropowatości kadłuba na powierzchni styku z czujnikiem piezoelektrycznym. Należy przy tym zwracać uwagę, aby warunki środowiskowe (wilgotność, temperatura itp.) były w normie.

\subsection{Wpływ odkształcenia zespołu czujnika na sygnał wibroakustyczny}

Niewłaściwe i nierównomierne naprężenia zespołu pomiarowego (sprężyny wraz z akcelerometrem, rys. 4) mogą być przyczyną znacznych zakłóceń wyników zmierzonych drgań. Efekt ten można zminimalizować przez zastosowanie specjalnej tulejki stabilizującej tor pracy sprężyny (rys. 5 i 6).

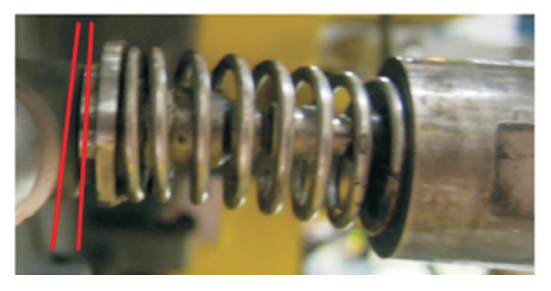

Deviations of the measuring system

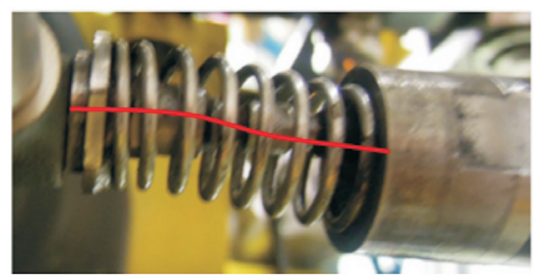

Deformation of spring of the measuring system
Fig. 4. Possible deformations of the measuring system Rys. 4. Możliwe odkształcenia układu pomiarowego

Zastosowanie tulejki stabilizującej spowodowało istotne zmniejszenie amplitudy drgań w zakresie wyższych rzędów, większych od 65 (rys. 7), natomiast dla małych rzędów < 25, amplitudy drgań wykazywane przez zespół z tulejką są większe, co należy odczytywać jako dodatkowe zakłócenie wprowadzone przez tulejkę.

\subsection{Wpływ zakłócenia tryboelektrycznego powstałego przy swobodnym przewodzie elektrycznym układu pomiarowego}

Podczas drgań przewodu elektrycznego czujnika mogą powstawać dodatkowe zakłócenia tryboelektryczne powodowane dynamicznymi naprężeniami w zespole pomiarowym. Zmniejszenie oddziaływania tych zakłoceń można osiągnąć dzieki zastosowaniu odpowiedniego przewodu oraz umocowanie go do układu pomiarowego za pomocą odpowiednich opasek (lub taśm), rys. 8.

Zamocowanie przewodu elektrycznego powoduje zwiększenie masy bezwładnej układu pomiarowego. W efekcie sygnał wibroakustyczny wykazuje większe amplitudy drgań w zakresie niższych Ord < 80 i większych Ord $>150$ rzędów, rys. 9. W zakresie średnich rzędów $80<$ Ord $<150$ amplitu-

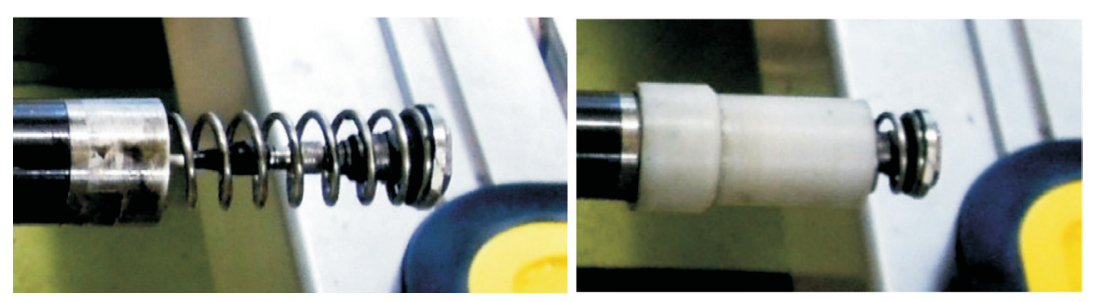


additional triboelectrical interferences caused by dynamic strain within the measuring system. Reduction of interaction of these interferences can be attained by use of a suitable wiring cable, and by fixing it to the measuring system with use of proper clamps (or tapes), Fig. 8.

Fixed wiring cable results in increased inertial mass of the measuring system. In result, the vibroacoustic signal shows a higher amplitudes of the vibrations in range of lower Ord $<80$ and higher Ord $>150$ orders, Fig. 9. In range of medium orders $80<$ Ord $<150$, amplitudes of the vibrations shown by the system with fixed cable are lower.

\subsection{Impact of surface roughness in area of contact of the sensor} with the tested object

In course of the test, the sensor is in contact with cylinder block of the engine on surface as obtained from casting process. Its roughness is not controlled, and depending on batch of raw castings, or supplier of the casting, can be different. It is possible, therefore,

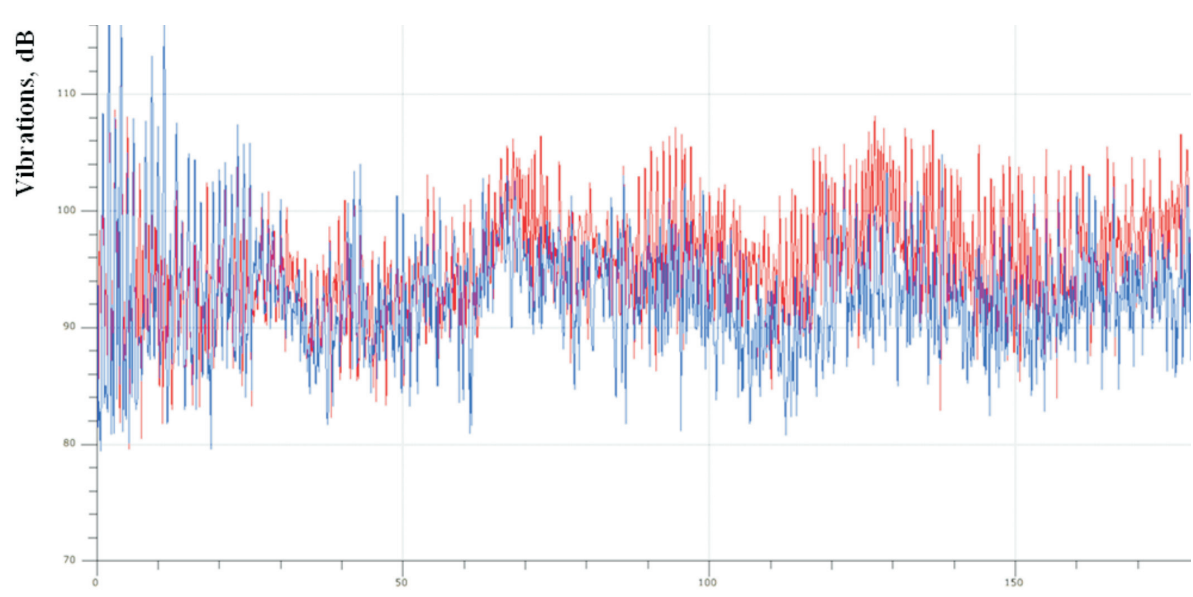

Fig. 7. Comparison of the signal from the order tracking analysis: blue colour - system with stabilizing sleeve, red colour - system without stabilizing sleeve

Rys. 7. Porównanie sygnału drgań analizy rzędowej: kolor niebieski-układ z tulejką stabilizująca, kolor czerwony - uktad bez tulejki stabilizujacej

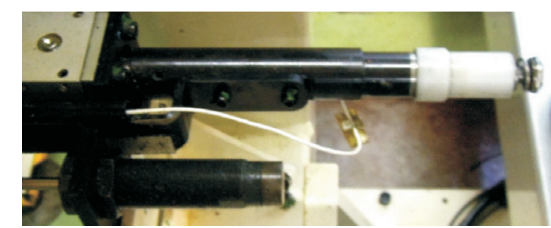

Free hanging wiring cable

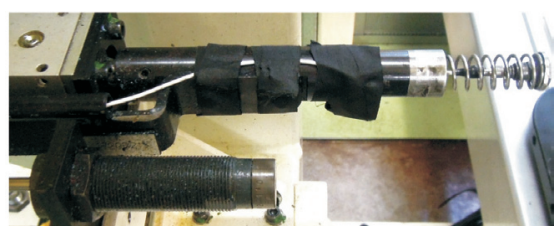

Wiring cable fixed with elastic tape
Fig. 8. Measuring system during the experiment: with free hanging wiring cable, and fixed with use of elastic tape

Rys. 8. Uklad pomiarowy podczas doświadczenia: z przewodem swobodnym i mocowanym przy użyciu taśmy elastycznej

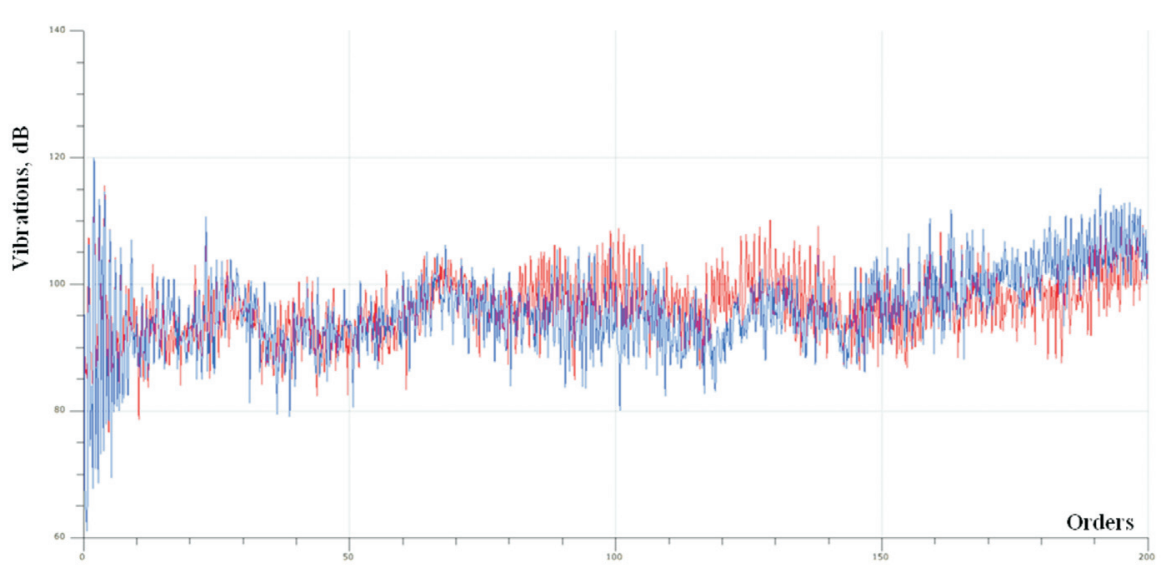

Fig. 9. Comparison of vibration signal of the order tracking analysis: blue colour - the measuring system with fixed wiring cable, red colour - the system with free hanging cable

Rys. 9. Porównanie sygnału drgań analizy rzędowej: kolor niebieski-układ z przewodem elektrycznym zamocowanym, kolor czerwony - układ z przewodem swobodnym

dy drgań wykazywane przez układ z zamocowanym przewodem są mniejsze.

\subsection{Wpływ chropowatości powierzchni styku czujnika z obiektem badanym}

Podczas badań silnika czujnik styka się z kadłubem silnika na powierzchni powstałej podczas odlewu. Jej gładkość nie jest kontrolowana i w zależności od partii odlewów lub producenta może być różna. Można zatem prszypuszczać, że przy stałej sile docisku czujnika będzie to miało wpływ na rejestrowany sygnał wibroakustyczny.

W celu określenie wpływu stanu powierzchni styku na wynik pomiarów porównano sygnały re-

to conclude that at constant pressing force of the sensor it could have an effect on recorded vibroacoustic signal.

To find influence of the contact surface's condition on results of the measurement it has been performed comparison of signals recorded by the sensor in contact with raw surface (raw casting) and with machined surface, Fig. 10. jestrowane przez czujnik przy styku z powierzchnią surową (odlew) i powierzchnią obrabianą, rys. 10.

Porównanie sygnałów przedstawione na rys. 11 wskazuje na istotne zmniejszenie amplitudy drgań dla wyższych rzędów Ord $>50$. W zakresie mniejszych rzędów Ord $<50$ wpływ obrabianej powierzchni jest nieznaczny. 


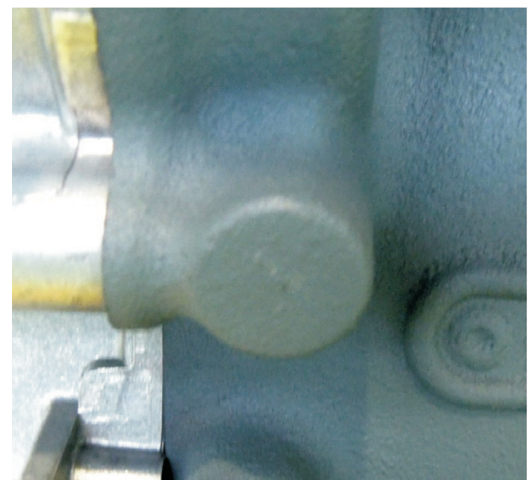

Raw contact surface with the sensor (casting)

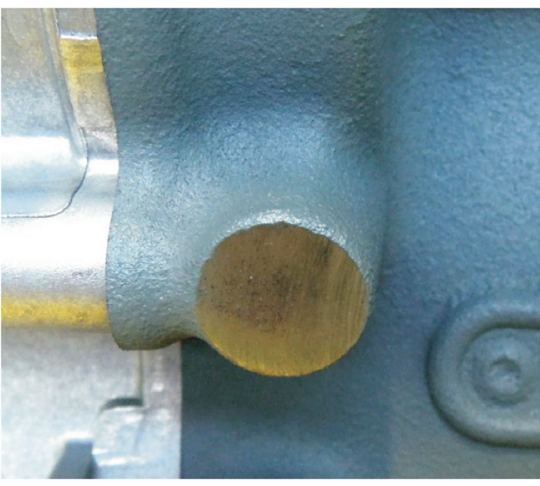

Machined contact surface with the sensor

3.4. Numeryczna ocena wpływu zakłóceń na wyniki pomiarów

W celu oceny wpływu badanych zakłóceń na sygnał wibroakustyczny zastosowano narzędzie DoE (Design of Experiments) komercyjnego programu MiniTab. Pozwala ono na ocenę istotności wpływu parametru wejściowego (zakłócenia) na uzyskiwane wyniki sygnału wibroakustycznego.

Do numerycznej obróbki wyników pomiarów przyjęto trzy czynniki wejściowe zgodnie z przedstawionym wcześniej planem eksperymentu (rys. 12):

- układ pomiarowy zespołu czujnika oryginalny i z tulejką stabilizującą,

Fig. 10. Surface of the cylinder block Rys. 10. Powierzchnia korpusu silnika

Comparison of the signals shown in the Fig. 11 points at considerable reduction of amplitude of the vibrations in case of higher orders Ord $>50$. In area of a lower orders Ord $<$ 50 , impact of the machined surface is insignificant.

\subsection{Numerical valuation of impact of interferences on} results of the measurements

To assess influence of investigated interferences on the vibroacoustic signal it has been implemented the DoE (Design of Experiments) tool of commercial MiniTab program. It enables to assess what is a significance of impact of the input parameters (interferences) on obtained results of the vibroacoustic signal.

To numerical processing of the measurement results the following three input factors were taken according to presented earlier plan of the experiment, Fig. 12:

- original measuring system with sensing unit and the system with stabilizing sleeve,

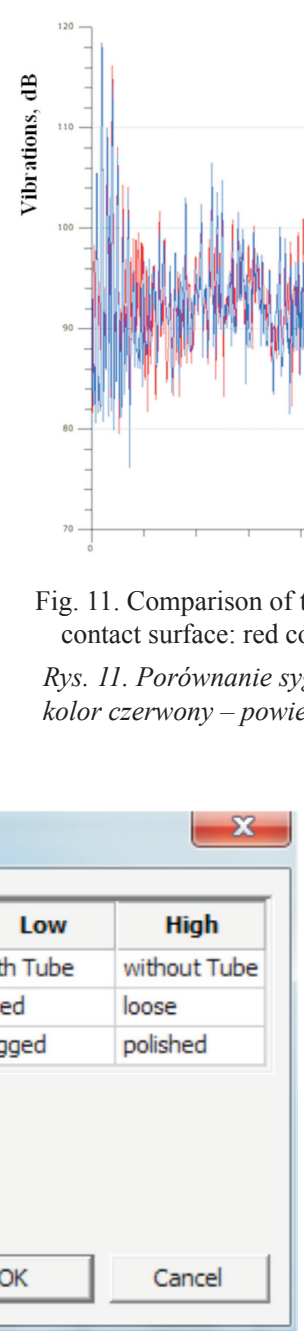

Fig. 12. View of control panel to input of the initial parameters

Rys. 12. Widok panelu wprowadzania parametrów wejściowych

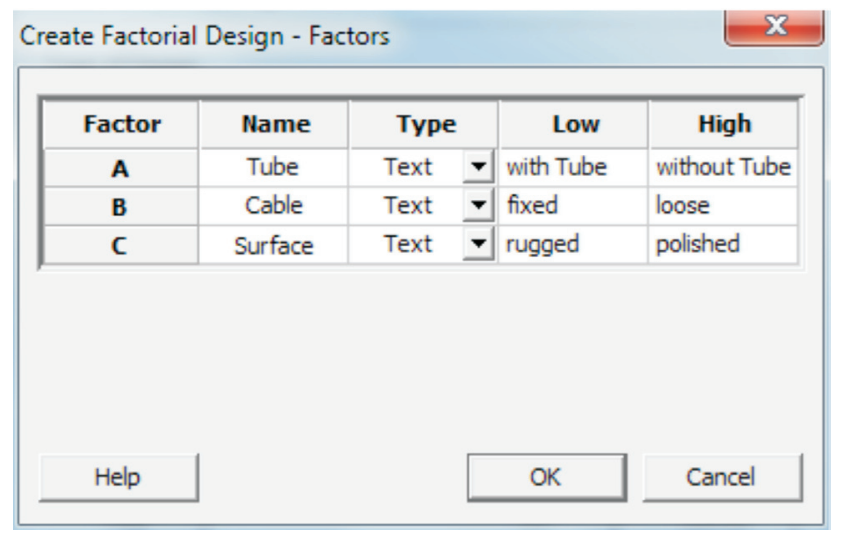

(odlew) lub obrabiana.

- układ z przewodem elektrycznym czujnika swobodnym i mocowanym,

- powierzchnia korpusu silnika surowa

W programie przyjęto następujace założenia: test z powtórzeniem oraz wartość współczynnika alfa równa 0,05 (maksymalne akceptowane ryzyko błędu).
Parametrem wyjściowym analizy numerycznej jest średnia wartość drgań dla 200 rzędów oznaczona symbolem Order99000_Mean - rys. 13.

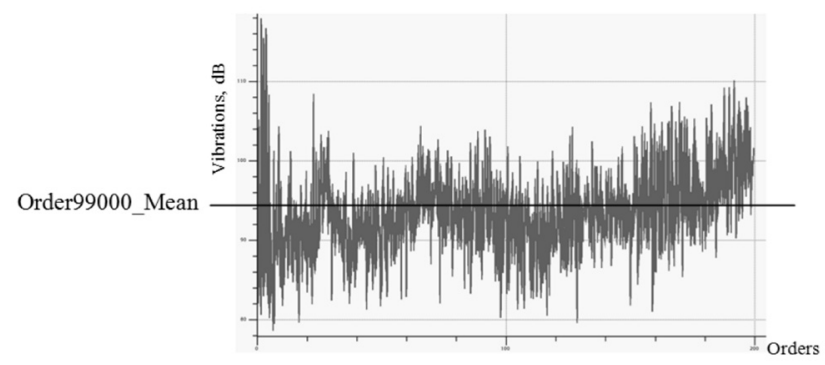

Fig. 13. Average value of the vibrations for 200 orders Rys. 13. Średnia wartość drgań dla 200 rzędów 
- the system with free hanging wiring cable and with fixed cable,

- raw surface of the cylinder block (casting) or machined surface.

The following assumptions were taken in the program: the test with repetition and value of the alfa coefficient equal to 0.05 (maximally accepted risk of error).

As the output parameter from the numerical analysis the average value of vibrations for 200 orders was taken, marked with the simbol Order99000 Mean, Fig. 13.

The analysis was acomplished according to the sequence shown in the Table 1, which additionally specifies values of the vibrations measured during the test.

\section{Analysis of results of the numerical investigations}

In the Fig. 14 are presented coefficients of obtained mathematical model, described by the equation (2). According to performed experiment, the real conditions are reflected by the model shown below in more than 99 percent.

$$
\begin{aligned}
& \mathrm{D}=94.447+0.281 \cdot \mathrm{x}_{1}-0.078 \cdot \mathrm{x}_{2}+ \\
& -1.204 \cdot \mathrm{x}_{3}-0.094 \cdot \mathrm{x}_{1} \mathrm{x}_{2}-0.440 \cdot \mathrm{x}_{1} \mathrm{x}_{3}+ \\
& +0.080 \cdot \mathrm{x}_{2} \mathrm{x}_{3}-0.040 \cdot \mathrm{x}_{1} \mathrm{x}_{2} \mathrm{x}_{3}
\end{aligned}
$$

where: $\mathrm{D}$ - value of vibrations, $\mathrm{x}_{1}-$ sleeve, $\mathrm{x}_{2}$ - wiring cable, $\mathrm{x}_{3}$ - surface.

To the mathematical model were taken values of the variables according to the Tab. 2 .

The Pareto diagram (Fig. 15) shows statistical significance of investigated factors during the experiment, and the red line depicting significance limit of the input factors.

Correctness of the model is confirmed by the residual diagrams, Fig. 16. Difference between anticipated values and measured values are acceptable.

Confirmation of creation of the mathematical model, suitable for the experiment, is enabled by finding optimal conditions to minimization of values of the vibrations. Target value of obtained vibrations equal to $93.5 \mathrm{~dB}$ was taken to the project.

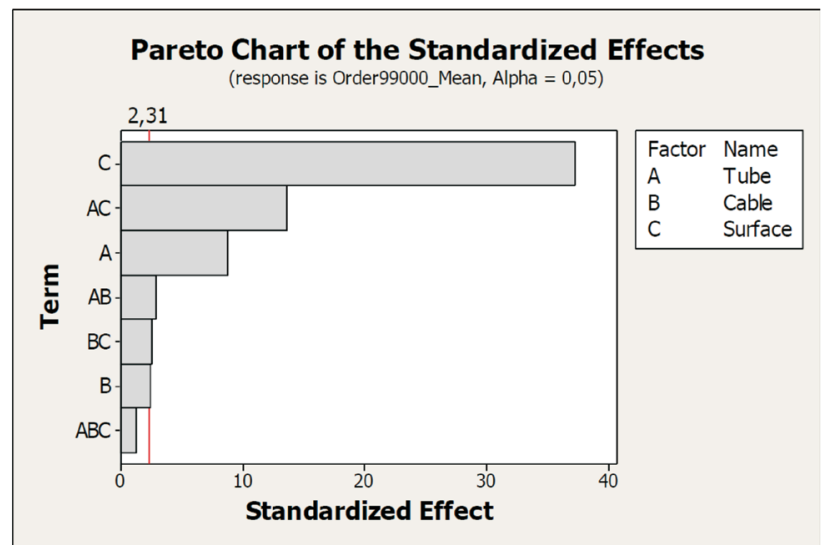

Fig. 15. Pareto diagram of the effects

Rys. 15. Wykres efektów Pareto
Table 1. Results of the experiment for three input variables Tabela 1. Wyniki eksperymentu dla trzech zmiennych wejściowych

\begin{tabular}{|c|c|c|c|c|}
\hline No. & Sleeve & $\begin{array}{c}\text { Wiring } \\
\text { cable }\end{array}$ & Surface & $\begin{array}{c}\text { Order99000 } \\
\text { Mean [dB] }\end{array}$ \\
\hline 1. & with sleeve & loose & grinded & 93.505 \\
\hline 2. & with sleeve & loose & grinded & 93.571 \\
\hline 3. & with sleeve & attached & rough & 95.118 \\
\hline 4. & with sleeve & attached & grinded & 93.267 \\
\hline 5. & without sleeve & attached & rough & 96.772 \\
\hline 6. & without sleeve & loose & grinded & 93.009 \\
\hline 7. & without sleeve & loose & grinded & 92.896 \\
\hline 8. & without sleeve & attached & rough & 96.396 \\
\hline 9. & without sleeve & attached & grinded & 93.122 \\
\hline 10. & without sleeve & loose & rough & 96.257 \\
\hline 11. & without sleeve & loose & rough & 96.060 \\
\hline 12. & with sleeve & loose & rough & 94.858 \\
\hline 13. & with sleeve & loose & rough & 94.792 \\
\hline 14. & with sleeve & attached & grinded & 93.265 \\
\hline 15. & with sleeve & attached & rough & 94.950 \\
\hline 16. & without sleeve & attached & grinded & 93.312 \\
\hline
\end{tabular}

Analizę wykonano według sekwencji podanej w tabeli 1, w której podano również dodatkowo wartości drgań zmierzonych podczas badań.

\section{Analiza wyników badań numerycznych}

$\mathrm{Na}$ rysunku 14 przedstawiono współczynniki otrzymanego modelu matematycznego określonego wzorem (2), gdzie: D - wartość drgań, $x_{1}$ - tulejka, $x_{2}$ - przewód, $\mathrm{x}_{3}$ - powierzchnia.

\begin{tabular}{|c|c|c|c|c|c|}
\hline \multicolumn{2}{|l|}{ Term } & Coef & SE Coef & $\mathrm{I}$ & P \\
\hline Constant & & 94,447 & 0,03223 & 2930,03 & 0,000 \\
\hline Tube & 0,562 & 0,281 & 0,03223 & 8,72 & 0,000 \\
\hline Cable & $-0,157$ & $-0,078$ & 0,03223 & $-2,43$ & 0,041 \\
\hline Surface & $-2,407$ & $-1,204$ & 0,03223 & $-37,34$ & 0,000 \\
\hline Tube $\star C a b l e$ & $-0,188$ & $-0,094$ & 0,03223 & $-2,92$ & 0,019 \\
\hline Tube $\star S u r f a c e$ & $-0,880$ & $-0,440$ & 0,03223 & $-13,64$ & 0,000 \\
\hline Cable^Surface & 0,160 & 0,080 & 0,03223 & 2,49 & 0,038 \\
\hline Tube*Cable*Surface & $-0,080$ & $-0,040$ & 0,03223 & $-1,24$ & 0,250 \\
\hline$S=0,128937$ & $E S S=0$, & 31988 & & & \\
\hline $\mathrm{R}-\mathrm{Sq}=99,538$ & $q$ (pred) & $=98,108$ & $R-5 q(a$ & $d j)=99$, & $11 \%$ \\
\hline
\end{tabular}

\section{Factorial Fit: Order99000_Mean versus Tube; Cable; Surface}

Estimated Effects and Coefficients for Order99000 Mean (coded units)

Fig. 14. Data to the mathematical model: 1 - coefficients, 2 - accurracy of the mathematical model

Rys. 14. Dane dla modelu matematycznego: 1 -współczynniki, 2 -doktadność modelu matematycznego

Table 2. Value of initial factors for the mathematical model

Tabela 2. Wartości czynników wejściowych dla modelu matematycznego

\begin{tabular}{|c|c|c|}
\hline \multirow{2}{*}{ Sleeve } & with sleeve & without sleeve \\
\cline { 2 - 3 } & -1 & 1 \\
\hline \multirow{2}{*}{ Wiring cable } & attached & loose \\
\cline { 2 - 3 } & -1 & 1 \\
\hline Surface & rough & grinded \\
\cline { 2 - 3 } & -1 & 1 \\
\hline
\end{tabular}




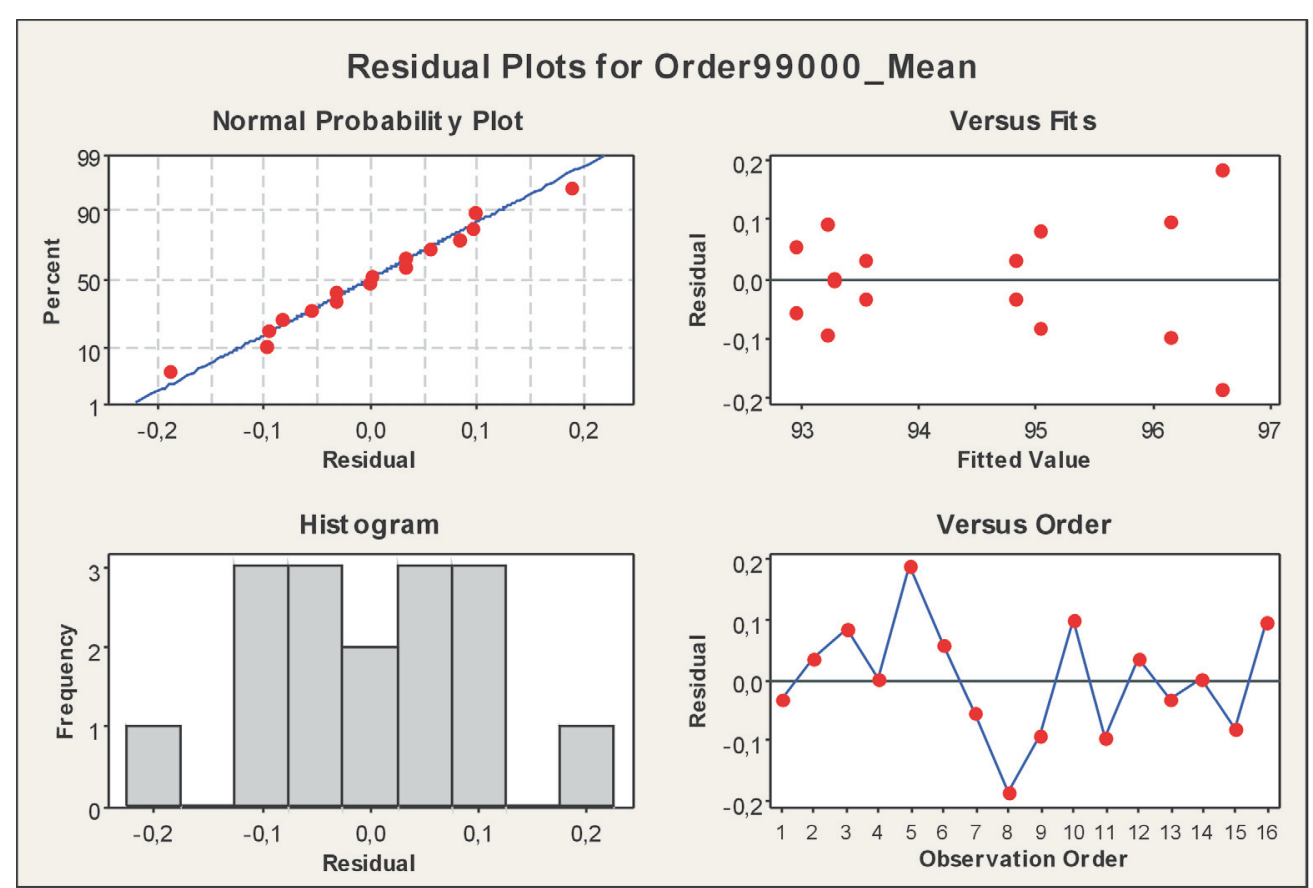

Fig. 16. Diagram of probability and residual diagram

Rys. 16. Wykres prawdopodobieństwa oraz resztowy
Według przeprowadzonego doświadczenia model ten odzwierciedla warunki rzeczywiste w ponad 99 procentach.

Dla modelu matematycznego przyjmujemy wartości zmiennych wg tabeli 2.

Wykres Pareto (rys. 15) przedstawia statystyczną istotność badanych czynników podczas doświadczenia wraz linią czerwoną wskazującą granicę istotności czynników wejściowych.

Poprawność modelu matematycznego potwierdzają wykresy resztowe (rys. 16). Różnice pomiędzy wartościami przewidywanymi a wartościami zmierzonymi są akceptowalne.

Results of the analysis of conditions are shown in the Fig. 17 , with marked optimal factors (red colour): spring with sleeve, loose wiring cable and grinded surface.

Impact of the contact surface with the sensor is significant and additionally results in decrease of average amplitude of measured vibrations and considerable reduction of scatter of the results (Fig. 18 and 19). Moreover, use of the stabilizing sleeve has an effect on reduction of amplitude of recorded vibrations and scatter of obtained results. Influence of attachment of the wiring cable is pointing at its small signifi-

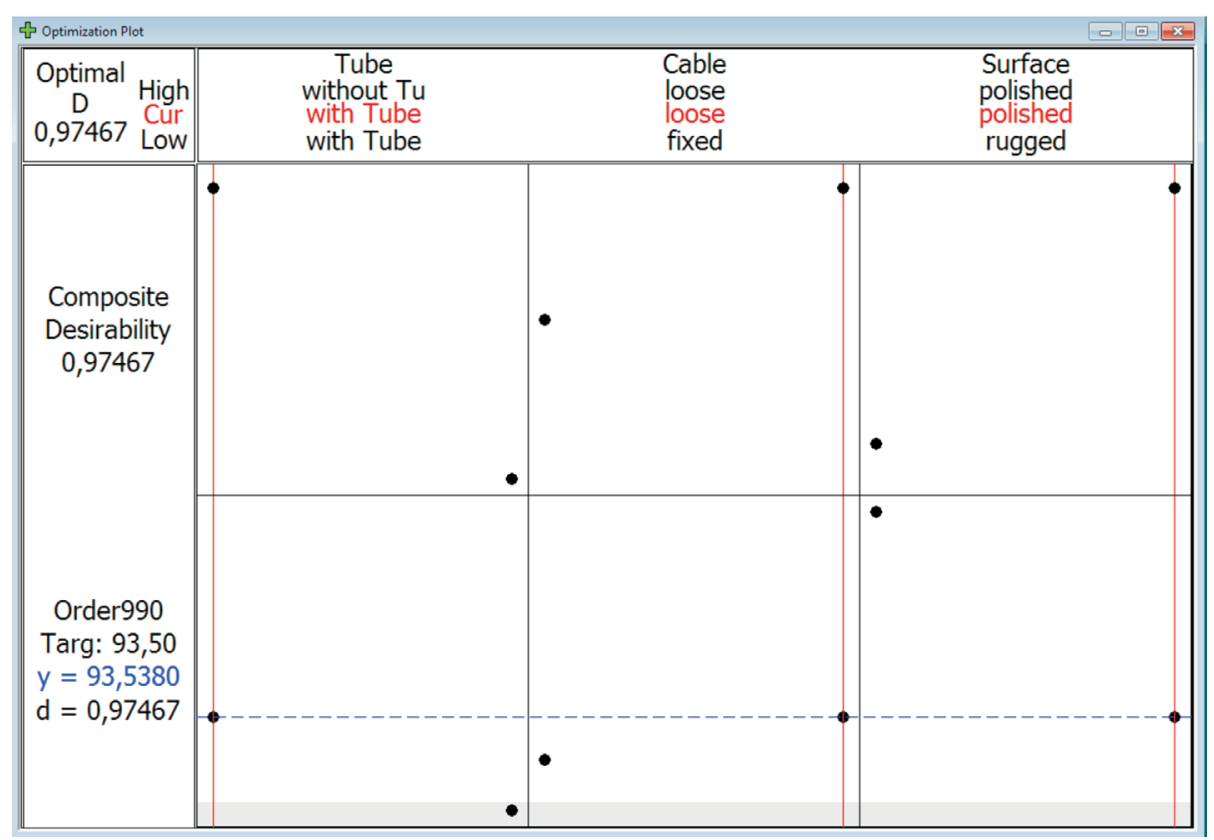

Fig. 17. Optimal input factors to minimization of measured vibrations Rys. 17. Optymalne czynniki wejściowe dla minimalizacji mierzonych drgań
Potwierdzenie utworzenia poprawnego modelu matematycznego dla doświadczenia umożliwia znalezienie optymalnych warunków, w celu minimalizacji wartości drgań. Przyjęto do projektu wartość docelową otrzymywanych drgań - 93,5 dB.

Wynik analizy warunków przedstawiono na rys. 17 z zaznaczonymi czynnikami optymalnymi (kolor czerwony): sprężyna z tulejką, przewód luźny oraz powierzchnia szlifowana.

Wpływ zmiany stanu powierzchni styku czujnika jest istotny i powoduje dodatkowo zmniejszenie średniej amplitudy mierzonych drgań oraz znaczne zmniejszenie rozrzutu wyników (rys. 18 i 19). Również zastosowanie tulejki stabilizującej wpływa na zmniejszenie amplirzutu otrzymywanych wyników. Wpływ mocowania przewodu wskazuje na jego małą istotność w procesie pomiaru drgań silnika spalinowego metodami wibroakustycznymi

\section{Wnioski}

Przeprowadzone badania wpływu zakłóceń na sygnał wibroakustyczny podczas testu zimnego silnika wskazują na istotne znaczenie dwóch czynników: stanu powierzchni styku czujnika tudy rejestrowanych drgań i roz- 
Two-Sample T-Test and CI: Order99000_Mean; Tube

Two-sample T for Order99000_Mean

$\begin{array}{lllll}\text { Tube } & \text { N } & \text { Mean } & \text { StDev } & \text { SE Mean } \\ \text { with Tube } & 8 & 94,166 & 0,828 & 0,29\end{array}$

$\begin{array}{lllll}\text { with Tube } & 8 & 94,166 & 0,828 & 0,29\end{array}$

Difference $=\mathrm{mu}($ with Tube) $-\mathrm{mu}$ (without Tube)

Estimate for difference: $-0,562$

$95 \% \mathrm{CI}$ for difference: $(-2,126 ; 1,002)$

T-Test of difference $=0($ vs not $=): T$-Value $=-0,81 \quad \mathrm{P}$-Value $=0,437 \quad \mathrm{DF}=9$

\section{Two-Sample T-Test and CI: Order99000_Mean; Cable}

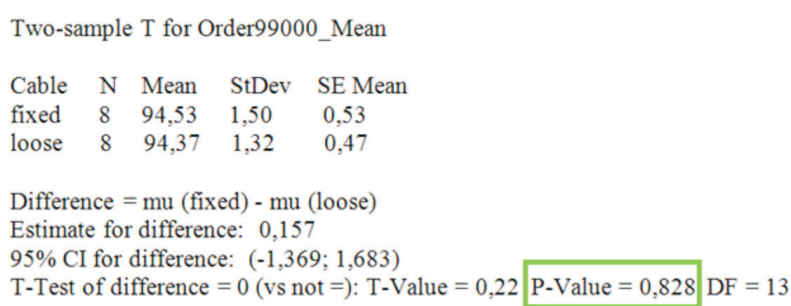

Two-Sample T-Test and CI: Order99000_Mean; Surface

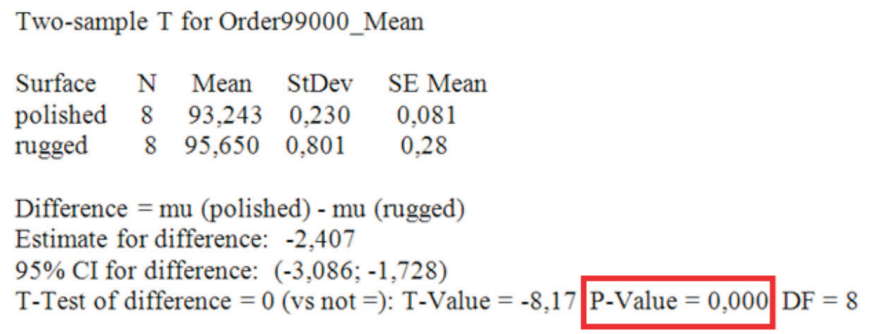

Fig. 18. Results of the $2 \mathrm{t}$ test for the following factors: sleeve, wiring cable, surface Rys. 18. Wyniki testu 2 t dla czynników: tulejka, przewód, powierzchnia
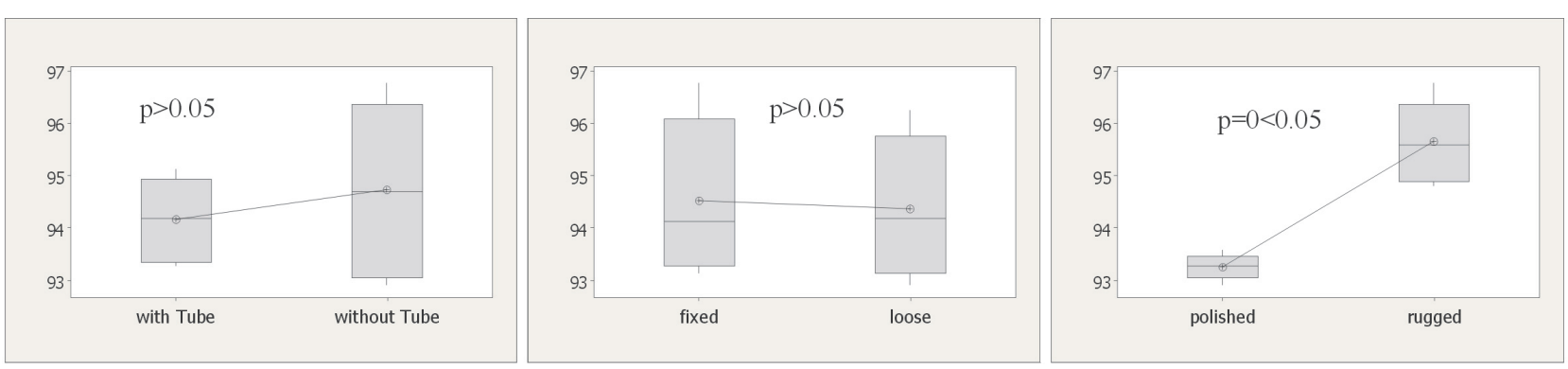

Fig. 19. Graphic presentation of the $2 t$ test results for the input factors: sleeve, wiring cable, surface

Rys. 19. Graficzne przedstawienie wyników testów 2t dla czynników wejściowych: tulejka, przewód i powierzchnia

cance in measuring process of engine vibrations with use of vibroacoustic methods.

\section{Conclusions}

Performed investigations of influence of the interferences on vibroacoustic signal during cold test of the engine are pointing at significance of two factors: conditions of contact surface of the cylinder block with the sensor and deformations of the compression spring. Effect of wiring cable of the sensor (free hanging or attached to cylinder block) is very small and can be considered as insignificant. Contact surface, machined with grinder, and use of the sleeve stabilizing deformations of the pressing spring should be considered as optimal conditions for carrying out the measurements.

Among investigated factors, use of grinding operation of contact surface on the cylinder block with piezoelectric sensor effects in the biggest changes of the vibroacoustic signal. Results obtained for many investigated engines are pointing at reduction of average amplitude of the vibrations for 200 orders shown in the DoE program. Simultaneously, it should be underlined that real vibrations of the engine are independent of whether the contact surface is raw or ma- z kadłubem silnika oraz odkształceń sprężyny dociskowej czujnika. Wpływ przewodu elektrycznego czujnika (swobodny i mocowany do korpusu) jest bardzo mały i może być uznany za nieistotny. Za optymalne warunki przeprowadzenia pomiarów należy uznać powierzchnię styku obrabianą szlifierką oraz zastosowanie tulejki stabilizującej odkształcenia sprężyny dociskowej.

Zastosowanie obróbki powierzchni styku czujnika piezokwarcowego z kadłubem przez szlifowanie szlifierką powoduje największe zmiany sygnału wibroakustycznego spośród badanych czynników. Wyniki uzyskane dla wielu egzemplarzy silnika wskazują na zmniejszenie średniej amplitudy drgań dla 200 rzędów wykazywanych przez program DoE. Należy równocześnie zaznaczyć, że drgania rzeczywiste silnika są niezależne od tego, czy powierzchnia styku jest chropowata, czy obrabiana. Fakt ten należy uwzględniać przy analizach sygnałów wibroakustycznych.

Najważniejszym praktycznym efektem obróbki powierzchni styku z czujnikiem piezoelektrycznym jest zmniejszenie rozrzutu sygnału wibroakustycznego. Powoduje to zmniejszenie wartości średniej amplitudy drgań w całym zakresie badanych rzędów Ord $=0-200$. Umożliwia to 
chined. This fact should be taken into considerations during analysis of vibroacoustic signals.

The most important practical effect of machining of the contact surface with the piezoelectric sensor is reduction of scatter of the vibroacoustic signal. It results in reduction of average value of amplitude of the vibrations in full range of investigated orders Ord $=0 \div 200$. It allows conscious restriction of control process limits of the engine during final test, what increases probability of separation of faulty engines.

Usage of the stabilizing sleeve in the sensing unit results in decrease of average amplitude of recorded vibrations. The tests have shown that such usage has considerably lower statistic significance within implemented mathematical model, comparing to grinding of the contact surface on the cylinder block.

Due to low significance of the interferences connected with change of position of the wiring cable, it has been decided to give up idea of attachment of the cable to body of the sensing unit.

In result of performed investigation, it has been already submitted proposal of additional machining of the cylinder block in area of contact with piezoelectric sensor, and actually the sleeves stabilizing the measuring unit in all cabins of the cold test have been installed. It should reduce scatter of recorded vibroacoustic signals and improve detection of faulty engines. świadome zaostrzenie limitów procesu kontrolnego silnika podczas testu końcowego, co zwiększa prawdopodobieństwo separacji wadliwych silników.

Zastosowanie tulejki stabilizującej w zespole czujnika powoduje zmniejszenie średniej amplitudy rejestrowanych drgań. Badania wykazały, że ma to jednak znacznie mniejszą istotność statyczną w zastosowanym modelu matematycznym w stosunku do szlifowania powierzchni styku korpusu silnika.

Ze względu na małą istotność zakłóceń związanych ze zmianą położenia przewodu elektrycznego postanowiono zrezygnować z mocowania go do obudowy zespołu czujnika.

W wyniku przeprowadzonych badań zgłoszono propozycję dodatkowej obróbki korpusu silnika w miejscu styku z czujnikiem piezokwarcowym i już obecnie zamontowano tulejki stabilizujące zespół pomiarowy we wszystkich kabinach testów zimnych. Powinno to zmniejszyć rozrzuty rejestrowanych sygnałów wibroakustycznych i poprawić wykrywalność wadliwych silników.

\section{Bibliography/Literatura}

[1] Barański R. Wavelet transfer function in analysis of vibrations in the system ,manual tool - operator's hand”. Falkowa funkcja przejścia w analizie drgań układu ,narzędzie ręczne - ręka operatora". AGH Kraków, praca doktorska, 2007.

[2] Brüel \& Kjær, Vibrations and shocks, Wibracje i wstrząsy, broszura, Nærum, Dania 1984.

[3] Cempel C. Fundamentals of vibroacoustic diagnostics of machines. Podstawy wibroakustycznej diagnostyki maszyn, WTN, Warszawa 1982.

[4] Janczewski Ł. Diagnostics of a selected self ignition engine’s units during cold test (vibroacoustic analysis). Diagnostyka uszkodzeń wybranych zespołów silnika o zapłonie samoczynnym podczas testu zimnego (analiza wibroakustyczna), ATH, Bielsko-Biała, praca doktorska, 2013.

[5] Lipski J. Diagnostics of manufacturing processes. Diagnostyka procesów wytwarzania, Politechnika Lubelska, Lublin 2013.

[6] Madej H. Processing methods of vibroacoustic signals in diagnostics of combustion engines. Metody przetwarzania sygnałów wibroakustycznych w diagnozowaniu silników spa- linowych. Zeszyty Naukowe Transport, Politechnika Śląska, nr 69/2010, s. 97-104.

[7] Stelmasiak Z., Rudnicki M. Use of vibroacoustic signals in diagnostics of automotive engines in cold test. Wykorzystanie sygnałów wibroakustycznych w diagnostyce silników samochodowych w teście zimnym, Logistyka 3/2014.

[8] Stelmasiak Z., Rudnicki M. Detection of damaged gear of combustion engines with use of vibroacoustic methods. Wykrywalność uszkodzeń przekładni zębatej silników spalinowych metodami wibroakustycznym. Combustion Engines $3 / 2014$.

[9] Stelmasiak Z., Rudnicki M. Vibroacoustic analysis of cold test for a gear and camshaft of automotive engine. Analiza wibroakustyczna testu zimnego dla przekładni zębatej i wałka rozrządu silnika samochodowego,. Konferancja Konmot, Kraków 25-26.09.2014.

[10] www.ec-diagnostics.pl

[11] www.pcb.com

[12] www.statsoft.pl
Prof. Zdzisław Stelmasiak, DSc., DEng. - Professor in the Faculty of Mechanical Engineering at University of Bielsko-Biala.

Prof. dr hab. inż. Zdzisław Stelmasiak-kierownik Katedry Silników Spalinowych i Pojazdów Akademii Techniczno-Humanistycznej w Bielsku-Biatej. e-mail: zstelmasiak@ath.bielsko.pl

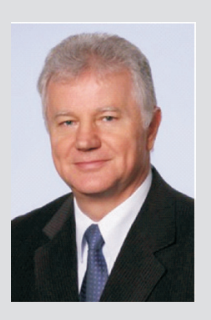

Mariusz Rudnicki, MEng. - doctoral student at the Faculty of Machine Design and Information Technology, University of Bielsko-Biała.

Mgr inż. Mariusz Rudnicki-doktorant na Wydziale Budowy Maszyn i Informatyki Akademii Techniczno-Humanistycznej w Bielsku-Biatej. e-mail: mariusz.rudnicki@fiat.com 